\title{
Notes on the Lecythidaceae of Peninsular Malaysia
}

\author{
G.T. Prance ${ }^{1}$
}

Key words

Abdulmajidia Barringtonia

Malaysia

new species
Abstract In preparation for the account of Lecythidaceae for the Flora of Peninsular Malaysia some changes involving new names are needed. The genus Abdulmajidia is reduced to synonymy with Barringtonia and the necessary new combinations are made. Three new species of Barringtonia from Malaysia are described, $B$. badia, B. glomerata and B. norshamii.

Published on 16 April 2010

\section{INTRODUCTION}

During the course of the preparation of the treatment of the Lecythidaceae for the Flora of Peninsular Malaysia three new species were found in the field and herbaria and the status of the genus Abdulmajidia was assessed. Since these involve nomenclatural changes, which are not permitted in the Flora, they are presented here.

\section{Abdulmajidia}

This genus was described by Whitmore (1974) for two species that differed from other Malaysian species of Barringtonia in having more than one seed in the fruit. This was the sole character upon which the genus was based. Recently two more species of Abdulmajidia were described by El-Sherif \& Latiff (2006) and Barringtonia rimata Chantar. was transferred to Abdulmajidia. My analysis of these two genera for the Flora found that the species placed in Abdulmajidia are very closely related to Barringtonia macrostachya (Jack) Kurz and $B$. scortechinii King. Outside of Malaysia several other species of Barringtonia sometimes have more than one seed, for example $B$. hallieri Knuth from Borneo, a species also closely related to this complex. These species all seem to fall within the variation of Barringtonia and so I will treat Abdulmajidia as a synonym of Barringtonia in the Flora and the necessary new combinations are made here.

\section{Barringtonia chaniana (Whitmore) Prance, comb. nov.}

Abdulmajidia chaniana Whitmore, Kew Bull. 29 (1974) 209 - Type: Y.C. Chan FRI 17547 (holo KEP), Malaysia, Johore.

\section{Barringtonia latiffiana (El-Sherif) Prance, comb. nov.}

Abdulmajidia latiffiana El-Sherif in El-Sherif \& Latiff, Folia Malaysiana 7 (2006) 49. - Type: R. Jaman \& H. Salleh RJ 2052 (holo UKMB), Malaysia, Kedah.

\section{Barringtonia maxwelliana (Whitmore) Prance, comb. nov.}

Abdulmajidia maxwelliana Whitmore, Kew Bull. 29 (1974) 210. — Type: K.M. Kochummen FRI 2898 (holo KEP), Malaysia, Perak.

${ }^{1}$ Royal Botanic Gardens, Kew, Richmond, Surrey, TW9 3AB, United Kingdom; corresponding author e-mail: gtolmiep@aol.com

\section{Barringtonia rimata Chantar.}

Barringtonia rimata Chantar. (1995) 691. - Type: Maxwell 84-37 (holo A; iso PSU, UKMB), Thailand, Songkhla.

Abdulmajidia rimata (Chantar.) El-Sherif \& Latiff (2006) 50.

Note - In this case a new combination is not necessary as this species was originally described in Barringtonia.

\section{Barringtonia zainudiniana (El-Sherif \& Latiff) Prance, comb. nov.}

Abdulmajidia zainudiniana El-Sherif \& Latiff, Folia Malaysiana 7 (2006) 46. - Type: Y.N. Lo \& Mahmud 111 (holo KLU), Malaysia, Kedah.

Note - I was unable to locate the type of this species at $\mathrm{KLU}$. It was based on a single collection and may prove to be a synonym of another Barringtonia, but I have transferred it here until it can be properly assessed.

\section{NEW SPECIES OF BARRINGTONIA}

\section{Barringtonia badia Prance, sp. nov. - Fig. 1}

Species $B$. fusiformis affinis sed foliis infra hirsutis, spathulatibus, in exsiccatis rubris differt. - Typus: B. Everett FRI 14310 (holo KEP; iso K, L), Malaysia, E boundary of Segamat Wildlife Reserve, NE of Segamat, $100 \mathrm{~m}$, 3 June 1970.

Tree to $35 \mathrm{~m}$ tall, bark grey/brown patched, smooth, inner bark pink. Leaves clustered at end of branches, lamina subsessile with short petioles $0-8 \mathrm{~mm}$ long, obovate-spathulate, broadest well above middle, subcoriaceous, drying reddish brown, 14-28 by $6-13 \mathrm{~cm}$, densely hirsute on venation beneath, tapering sharply towards base, mucronate at apex, the mucro 10-16 $\mathrm{mm}$ long; margins serrate-crenulate; midrib prominulous above, prominent beneath; primary veins $16-21$ pairs. Cataphylls lanceolate, 8-10 mm long. Inflorescence terminal, pendulous, the rachis to $1 \mathrm{~m}$ long, densely ferruginous pubescent. Flowers sessile, small 3-4 mm long; calyx open in bud; hypanthium and sepals densely ferrugineous pubescent on exterior; petals ovate, c. $5 \mathrm{~mm}$ long; stamens $1.5-2 \mathrm{~cm}$ long, in 3 whorls, the inner one staminodal. Fruit ovoid, $7-10$ by $3-5 \mathrm{~cm}$, green turning brown with age, exocarp smooth, ferrugineous puberulous, rounded or tapering towards apex and base.

Habitat - Collected in disturbed forest and secondary forest at low altitudes on non-flooded ground. 


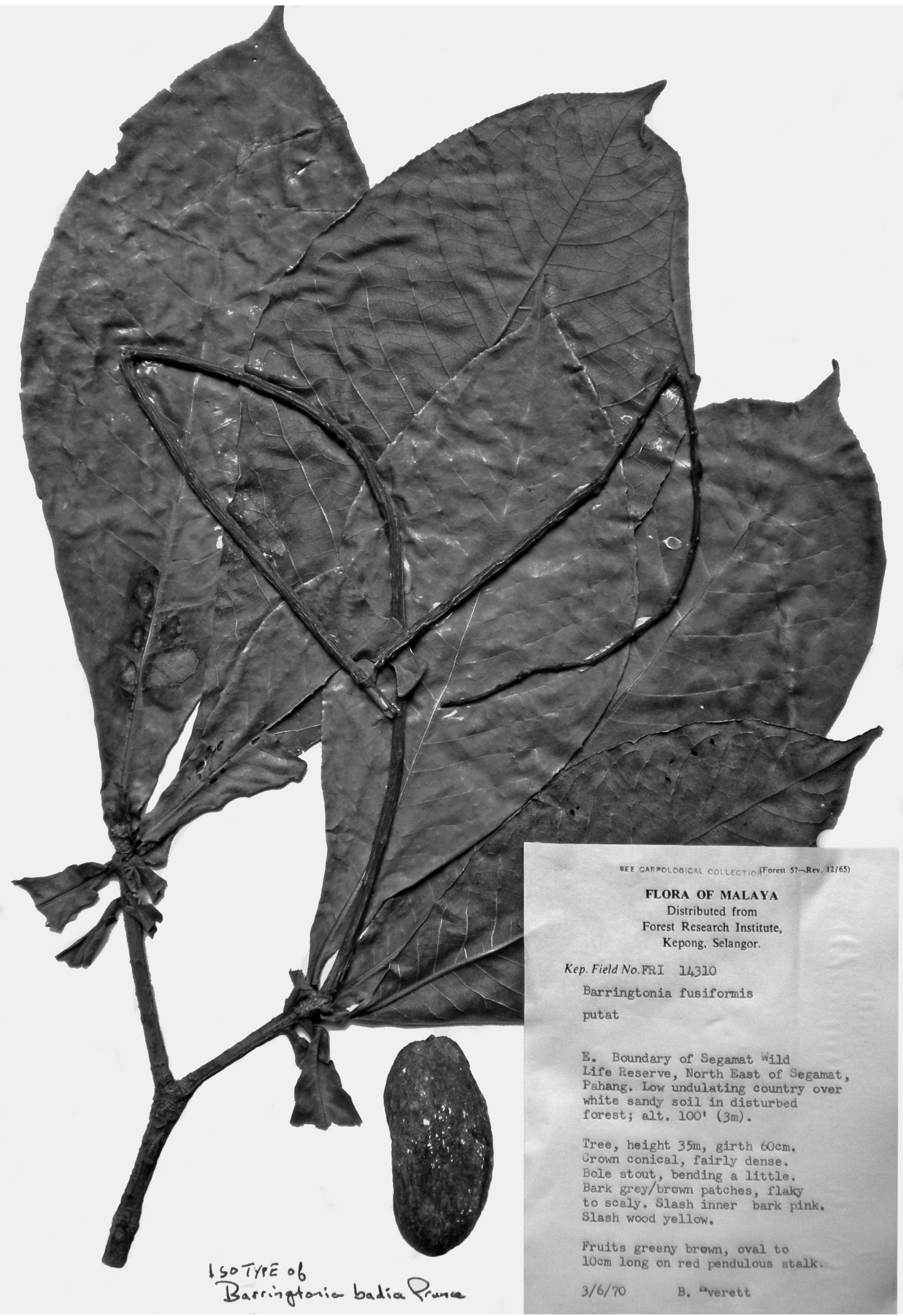

Fig. 1 Photo of type specimen of Barringtonia badia Prance (Everett FRI 14310). 

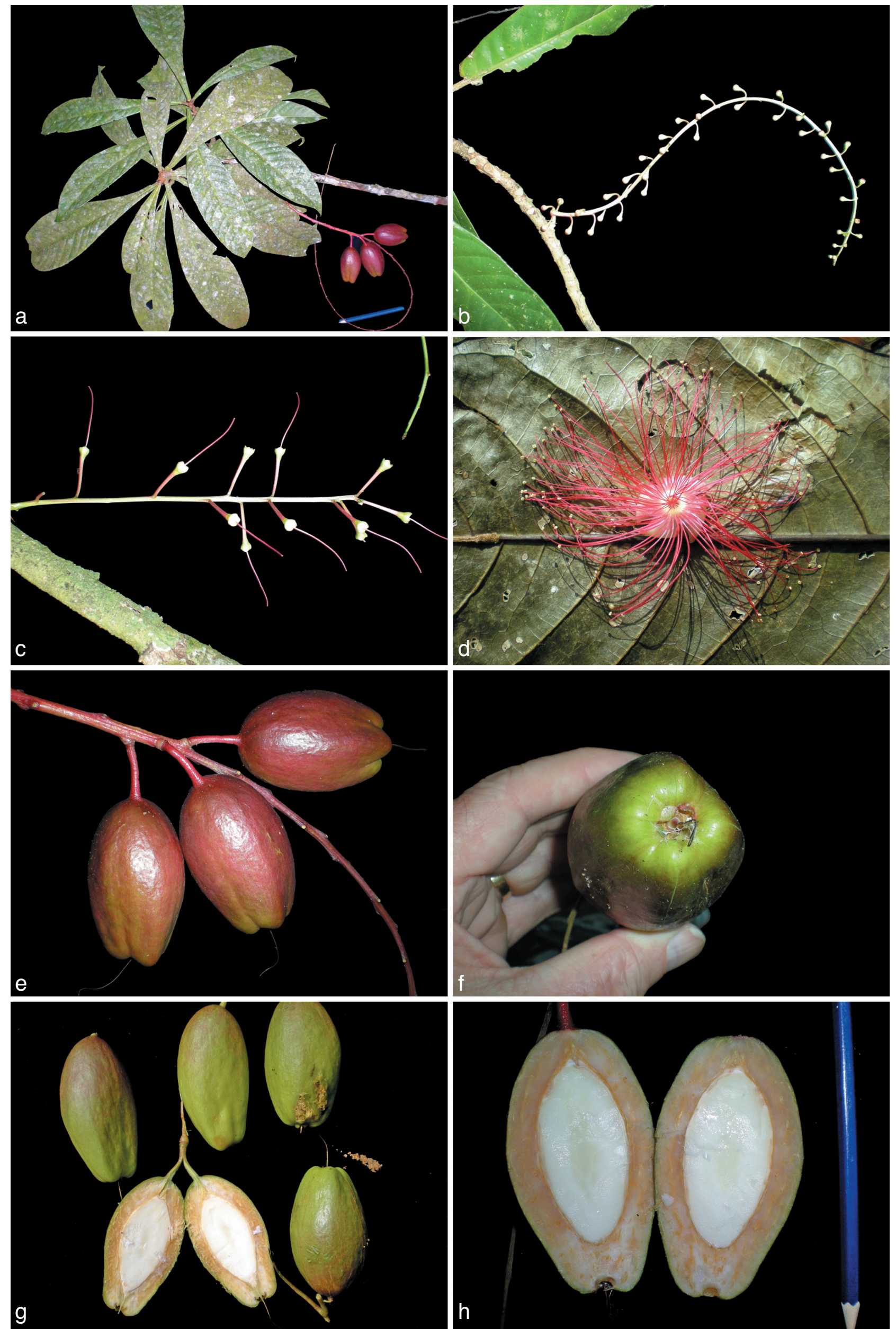

Fig. 2 Barringtonia norshamiae Prance. a. Habit; b. inflorescence; c. flowers without stamens; d. fallen stamens; e-h. fruit (a, f-h. Prance et al. 30888; b. Prance et al. 30890; c, d. Prance et al. 30891). 
Note - This species is closest to $B$. fusiformis King from which it differs in the hirsute underside of the leaves, the spathulate shape being much broader well above the midpoint, and in the smaller flowers and the broader, larger fruit. The specific name refers to the distinctive reddish brown colour of the leaves of the dried herbarium specimens.

Additional material examined. MALAYSIA, Pahang, E edge of Chini FR, S of Tasek Chini, 500 m, 13 Aug. 1970 (fr), Everett FRI 14552 (K, KEP); E boundary of Segamat Wildlife Reserve, 3 June 1970 (fl), Loh Hoy Shing FRI 17150 (K, KEP, L). Terengganu, Gunong Tebu FR, 700 m, 7 July 1969 (fr), Selvaraj FRI 13028 (K, KEP, L). Johore, Labis FR below Gunong Besar massif, 2 miles E of Kg. Tepoh, 180 m, 18 March 1970 (fl bud), Everett FRI 14085 (KEP, K, L), same locality and date, Everett FRI 14093 (K, KEP, L).

\section{Barringtonia glomerata Prance, sp. nov. - Fig. 3}

Species $B$. macrostachya affinis sed foliis maioribus, latioribus, mucronatis, floribus ad apicem rachidis glomeratis differt. - Typus: Md. Haniff SFN 21071 (holo SING; iso K), Malaysia, Kedah-Perak Boundary, Bukit Kuala Bintang, Gunong Bintang, 17 April 1928.

Tree c. $10 \mathrm{~m}$ tall, twigs glabrous. Leaves grouped towards end of branches, petioles $6-10 \mathrm{~cm}$ long, glabrous, swollen at junction with stem; lamina oblong, coriaceous, $30-38$ by 11-15 $\mathrm{cm}$, glabrous on both surfaces, abruptly mucronate at apex, the mucro 5-6 mm long, tapering to cuneate base, decurrent for $1.5 \mathrm{~cm}$ onto petiole; midrib prominulous above, prominent beneath; primary veins 16-19 pairs, venation reticulate on both surfaces; margins entire and slightly undulate. Cataphylls not seen. Inflorescence terminal, the rachis (in bud) $25 \mathrm{~cm}$ long, 6-7 mm thick, glabrous, flaking when dry. Flowers grouped at extreme tip of rachis, sessile; bracts broadly ovate with fine mucronate apex, 10 by $13 \mathrm{~mm}$; calyx closed in bud; hypanthium conical, c. $5 \mathrm{~mm}$ long, glabrous, slightly tetragonous; sepals broadly ovate, c. $1 \mathrm{~cm}$ long, mucronate; stamens in 4 or 5 whorls, the inner one staminodal; filaments c. $4 \mathrm{~cm}$ long. Fruit unknown.

Habitat - No data on habitat.

Note - This species is closest to $B$. macrostachya but differs in the clustered flowers at the tip of the inflorescence rachis, the broader leaves with entire not crenate margins and the abrupt mucro at the apex rather than a thin long acumen. Known only from the type collection from the Kedah-Perak border.

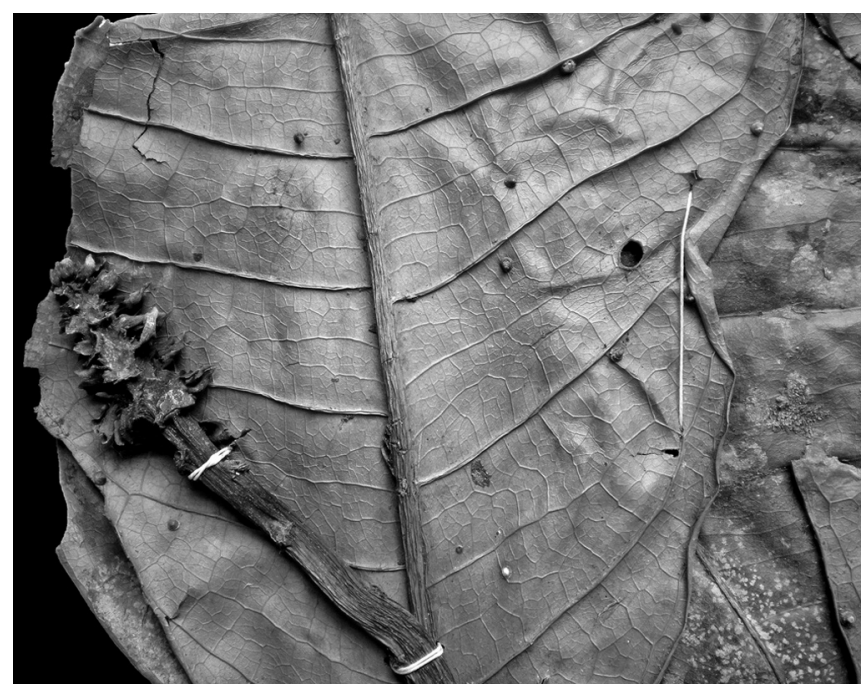

Fig. 3 Photo of type specimen of Barringtonia glomerata Prance (Haniff SF 20171).

\section{Barringtonia norshamiae Prance, sp. nov. - Fig. 2}

Species B. racemosa affinis, floribus parvioris, fructibus maioribus haud tetragonatis, foliis ad basim cuneatis differt. - Typus: B. Everett FRI 14099 (holo KEP; iso K, L), Malaysia, Johore, S. Segamat, N of Kg. Tepoh, in Gunong Besar Massif, Labis FR, 600 m, 19 March 1970.

Small tree 8-18 m tall; bark brown to grey, thickly fissured, inner bark pink. Leaves grouped towards end of branches arranged in storeys, subsessile, petioles $0-5 \mathrm{~mm}$, slightly winged; lamina chartaceous, narrowly oblong, $15-37$ by $4-9$ $\mathrm{cm}$, glabrous on both surfaces, acuminate at apex, the acumen $8-15 \mathrm{~mm}$ long, tapering gradually to a cuneate base, margins serrate-crenulate, slightly revolute; midrib prominulous above, prominent beneath; primary veins 14-24 pairs, prominent beneath. Cataphylls lanceolate, membranous, to $3 \mathrm{~cm}$ long. Inflorescence terminal or ramiflorous, pendulous, the rachis glabrous. Flowers with pedicels 9-17 mm long; calyx open in bud; hypanthium conoid, 2-3 mm, glabrous; sepals ovate, c. 2.5 by $2 \mathrm{~mm}$, glabrous; petals cream; stamens in 4 whorls the inner one staminodal, pink. Fruit ovoid, $7.5-8$ by $3-4 \mathrm{~cm}$, terete, exocarp smooth, glabrous, green tinted pink when mature, with 4 knob-like protrusions at base.

Habitat - Mixed lowland dipterocarp forest growing near rivers or among rocks, to $750 \mathrm{~m}$.

Note - This species differs from B. racemosa (L.) Spreng. in the larger ovoid not angled fruit, the much smaller flowers on long pedicels and the tapered leaf bases. It differs from $B$. revoluta Merr. with which it has been confused, in the smaller flowers, the much thinner chartaceous leaves that are almost sessile and with only slightly revolute margins. The specimens cited here has been variously filed in herbaria under $B$. racemosa, $B$. revoluta and $B$. fusiformis and Payens (1967) identified some of this material as $B$. revoluta. The latter species as defined here occurs only in Borneo and the Philippines, but not in Peninsular Malaysia. This species is named for Norsham Yaakob, a student of Barringtonia at the Forest Research Institute Malaysia (FRIM).

Additional material examined. MalAYSIA. Johore, S. Segamat, N of Kg. Tepoh, in Gunong Besar Massif, Labis FR, 600 m, 14 March 1970 (fl, fr), Everett FRI 14041 (K, KEP, L); 13 March 1970 (fr), Everett FRI 14021 (K, KEP, L); Labis FR, Bekok, near waterfall, 5 April 1972 (fl), Kochummen FRI 16508 (K, KEP, L). Pahang, Tembeling, 26 May 1932 (fr), Henderson SFN 24523 (K, MO, SING); Jenderak Estate, 29 March 1959 (fl), Kadim \& Noor 76 (K, L, SING); Kuala Lompat Game Reserve, 15 April 1967 (fl bud), Whitmore FRI 3503 (KEP), same locality, 16 April 1967 (st), Whitmore FRI 352 (KEP, L); Sungai Bantang Recreational Forest, Labis, Bekok, 10309"E, $2^{\circ} 18^{\prime \prime} \mathrm{N}$, 21 June 2008,(fr), Prance, Yaacob \& Velautham 30888 (K, KEP, KLU), 30890 (K, KEP, KLU), 30891 (K, KEP, KLU).

Acknowledgements I am grateful to the Forest Research Institute Malaysia (FRIM) and the Flora of Peninsular Malaysia Project for supporting a visit to Malaysia to study Lecythidaceae in the field and herbarium, to Norsham Yaakob and Elango Velautham for accompanying me on a field trip to Johore, and to the Royal Botanic Gardens, Kew for facilities to work in the herbarium.

\section{REFERENCES}

Chantaranothai P. 1995. Barringtonia (Lecythidaceae) in Thailand. Kew Bulletin 50: 677-694.

El-Sherif IM, Latiff A. 2006. A taxonomic revision of Abdulmajidia Whitmore (Lecythidaceae). Folia Malaysiana 7: 41-54.

Payens JPDW. 1967. A monograph of the genus Barringtonia (Leythidaceae). Blumea 15: 157-263.

Whitmore TC. 1974. Abdulmajidia a new genus from Malaysia. Kew Bulletin 29: $207-211$ 